Paul Stepney, $\mathrm{PhD}$

Adjunct Professor of Social Work

School of Humanities and Social Sciences

Tampere University, Finland

\title{
OLDER PEOPLE IN THE SHADOW OF THE SOCIAL CARE MARKET: EUROPEAN SOCIAL MODELS, POLICY DILEMMAS AND PRACTICE CHALLENGES CONCERNING THE CRISIS IN LONG TERM CARE
}

\section{Abstract}

The full extent of the crisis in long term care (LTC) was cruelly exposed by the recent spread of the corona virus throughout Europe, highlighting the vulnerability of many frail older people especially in care homes. The object of this article is to unravel the nature of the crisis in LTC, assess its impact on older people and analyse the challenges facing policy makers and practitioners. The UK provides a primary focus as its community care reforms have set a benchmark for reform elsewhere in Europe. Hence, its mixed economy of provision, overt consumerism and use of the market to contain costs will be subject to critical scrutiny. Reference will be made to policy in other European welfare states and the challenges raised by recent EU reports on LTC, to meet the needs of Europe's ageing population. Different welfare models will be assessed to establish which policy framework delivers the most effective and integrated care services for vulnerable older citizens. The debate will be illustrated by examining contemporary issues of concern, such as, hospital discharge of older people, risk management dilemmas in practice and escalating cost of LTC. In this article an interpretive approach to knowledge production is adopted drawing on documentary sources, including case studies, official reports and empirical research evidence. Analysis does not follow a strict comparative design, but reflects a more investigative essay. It was found that while a focus on risk continues to shape mainstream practice, there is increasing recognition of the need to develop more extensive community based LTC with an emphasis on prevention and empowerment. There is good research evidence for investing in rehabilitation, integrated provision and person-centred home care for older people. The article concludes with a practice recommendation to this effect.

Keywords: long term care, older people, community care

\section{Introduction}

The full extent of the ongoing crisis in long term care (LTC) was cruelly exposed by the recent spread of the corona pandemic throughout Europe, which highlighted the vulnerability of many frail 
older people especially in care homes. Residents in UK care homes were exposed to the Covid-19 virus from older people hastily discharged from hospital without being tested. Between March and June 2020 , the death rate in care homes quickly rose leading to more than 16,000 deaths (a third of all UK fatalities), representing a serious failure in policy to protect many of Britain's most vulnerable older people (Booth and Duncan, 2020). Alongside this older people living in the community have been "shielding" at home with overstretched social services only able to maintain skeletal support. This means that with no friends or relatives permitted to visit, in either care homes or private residences and with services reduced to a minimum, social isolation and loneliness now makes an already difficult situation worse.

When we turn to supporting older people living in the community rather than in care homes we begin to find more extensive variation. Across Europe, between $50 \%$ and $75 \%$ of all formal LTC is provided in the community (Eurostat, 2018). Noting that there is a large variation in funding, organisation and delivery of community-based care services, an influential EU report on LTC (Spasova et al., 2018) identified four Europe wide problems:

- problems of access and adequacy of LTC provision

- issues concerning carers

- problems concerning quality of provision

- long term financial sustainability.
These problems present a challenge for all EU member states and progressive policy solutions will need to be found if the ongoing crisis in LTC is to be tackled and effectively managed (Spasova et al., 2018).

Given the wide variations across Europe a definition of key terms may be helpful. The care homes sector consists of residential and nursing homes, the latter for older people assessed by a qualified nurse or doctor as having higher health needs. In addition, the broad umbrella term community care may be defined as 'the network of care which will maintain people or restore people to independent living... enabling them to live in their own homes' (Centre for Policy on Ageing, 1990, p. 16). The care will usually be organised by social work and health-care professionals after a needs-led assessment and delivered by a range of care staff. The care will typically include domestic care (shopping, cleaning, housekeeping and so on) and possibly personal care, as well for those with higher levels of dependency (this will include assistance with daily living, such as, washing, getting in and out of bed, dressing, feeding and toileting).

In this article, against the backdrop of the current corona pandemic, the impact of the ongoing crisis in LTC for older people will be examined. Britain's mixed economy of provision and care market will be the primary focus and subject to critical scrutiny, including the conflicts, contradictions and divisions inherent in policy. Reference will be made to policy in other European welfare states and the four challenges raised by the EU report 
on LTC (Spasova et al., 2018) including of course the demographic challenge of meeting the needs of Europe's increasingly ageing population. One of the crucial questions concerns which European social welfare model provides the most helpful policy framework for delivering effective and integrated care services for vulnerable older citizens. The debate will be illustrated by examining contemporary issues of concern, including the hospital discharge of older people, risk management dilemmas in practice and escalating cost of LTC. Finally, the article will conclude by identifying key trends and linking the policy analysis with a brief recommendation for practice.

\section{The challenge of old age alongside an emerging crisis in care}

Old age is a concept that understandably evokes strong feelings in us all - what will it be like when we are old, how will we cope especially if our health begins to deteriorate, and who will look after us? Importantly how will we be treated in society - as a wise and respected elder like the Omaha native Indians in North America or seen as a burden on the state and a nuisance to be cast aside and forgotten about in some impersonal institutional social warehouse? The Beatles song, "When I'm sixty-four", written by Lennon- McCartney and recorded in 1967, captures the fears of old age:

When I get older losing my hair, Many years from now...
Will you still need me, will you still feed me

When I'm sixty-four

Copyright: Northern Songs LTD (1967)

Whatever conceptualisation of old age is adopted, it is clear that demand for health and social care is set to rise exponentially in every European country over the next 50 years (European Commission, 2018). There is every expectation that increasing demand will occur at a time when there are likely to be continuing resource constraints on public services (Stepney, 2018), together with a predicted decline in the number of informal carers able and willing to care (Thompson and Thompson, 2005). This is due to a number of factors - see the impending crisis of resources below. The outcome is a deepening crisis in care. In many European countries the crisis has already arrived and three contributing factors can be identified: First, demographic trends which highlight Europe's increasingly ageing population; second, a serious crisis of resources, and third concerns about the availability and quality of care. Let us look at these three factors in more detail.

\section{Europe's ageing population}

The population of Europe is clearly ageing. The proportion of the population 65 years and older is projected to increase from $18.9 \%$ in 2015 to $27.8 \%$ in 2050 as the post war "baby boomers" retire (Eurostat, 2018). The European Commis- 
sion's (2018) Ageing Report shows that the total population of the EU is projected to increase from 511 million in 2016 to 520 million in 2070 . However, if the retirement age population is set to rise then the working age population (those between 16 and 64) is moving in the opposite direction and projected to decrease from 333 million in 2016 to 292 million in 2070. The old-age dependency ratio in the EU (the ratio of people aged 65 and over relative to the working age population) is projected to increase substantially from $29.6 \%$ in 2016 to $51.2 \%$ in 2070 .

If we look at those over 80 , often referred to as "the very old", we see similar trends. The proportion of Europe's population of those 80 or over is projected to increase dramatically from $5.3 \%$ in 2015 to $12.3 \%$ by 2080 . Very old people are increasing as a proportion of Europe's retired population, and now (in 2020) represent almost $22 \%$ of all older people (European Commission, 2018).

These projected statistics reflect assumptions about fertility rates, life expectancy and migration flows and, importantly, will have resource implications and fiscal costs linked to pensions, health care and LTC. What this basically means is that the fiscal costs of supporting the rise of Europe's ageing population will largely fall on working age people - a slowly shrinking population. This is already creating a crisis of resources, with less people contributing to the cost of LTC through taxes and social insurance contributions.

\section{The impending crisis of resources and concerns about the availability of care}

While many older people care for themselves, with advancing age comes an increasing likelihood of ill health, disability and mobility problems. In fact, people are known to consume on average a similar amount of health resources in the last year of their life as the rest of their life (Stepney, 2018). This means that we are going to require substantial additional funds for health and social care in the very near future, at a time when the number of informal carers, particularly women, is projected to fall. In the past older people relied heavily on informal care within the family, especially in southern Europe and the Mediterranean countries. But this has begun to change due to more women in the labour market, marriage breakdown and higher divorce rates, reductions in family size, greater geographical mobility, community fragmentation and carers growing older (Anttonen, Baldock and Sipilä 2003; Walker, 2005). At the heart of the crisis of resources is the realisation that women are no longer able and willing to accept sole responsibility for informal care.

Further, the crisis of resources in LTC has led to a rising demand on state services at a time when governments have been under pressure to contain welfare costs in order to improve their competitiveness in global markets. Economic globalization has reshaped national economies during a period when the rise of GDP has been slowing down in both European nations as well as globally (Eurost, 2018). This has 
forced Governments to contain the rising cost of welfare by enforcing stricter eligibility criteria, charging for services and restricting access to the most vulnerable or high risk. The result has been a rationing of state support and an increase in unmet need (Stepney, 2018).

The crisis in funding LTC and concerns about availability means that one of the unintended consequence of policy has been the creation of an emerging "care gap". Only the more affluent pensioners can buy in and purchase the care that they

\section{The social construction of dependency in old age}

Social status after retirement has been found in a number of studies to correlate with employment status prior to retirement (Walker, 2005; Aquino et al., 1996). This means that those with higher incomes are more likely to accumulate savings, property and occupational pensions. As well as the effects of class, race and culture, women do worse in all occupational categories simply because they have on aver-

Figure 1: Labour market participation rates of older people

\begin{tabular}{|l|c|c|c|}
\hline Age 65 and over & All \% & Women \% & Men \% \\
\hline UK & 5.1 & 3.5 & 7.4 \\
\hline Germany & 2.7 & 1.6 & 4.4 \\
\hline US & 12.2 & 8.6 & 17.1 \\
\hline
\end{tabular}

Source: Anttonen, Baldock and Sipilä 2003

need through the expanding private care market. This has left large numbers of older people dependent on state benefits whose real value has not kept up with inflation (Eurostat, 2018). It is estimated that a substantial number of people over 65 are living in or on the margins of poverty. In 2014 over 16 million older people (age $65+)$ were at risk of poverty and $18 \%$ were categorised as poor in the EU (Antczak and Zaidi, 2016). While the vast majority of older people wish to keep their independence, they have increasingly become dependent upon the state, their families and voluntary or 'third sector' care to meet their everyday needs. This dependency is socially constructed and related to class, culture, ethnicity and gender. age lower earnings. Across Europe women are required to retire earlier and proportionately fewer women than men work on after reaching retirement age (Anttonen, Baldock and Sipilä 2003). Figure 1 illustrates this for UK, Germany and US.

There are a number of reasons for variable labour market participation rates among older people. According to Walker (2005) the most fundamental reason is that social and economic policies tend to act together in the overall management of the economy. This accounts for the fixed retirement age, to ease older workers out of the labour market. The assumption that older workers are less productive and therefore dispensable is highly contested, and there is a lot of anecdotal evidence to 
suggest the opposite - university professors being just one example! The state has sometimes incentivised the reduction in older workers by introducing early retirement schemes and limiting retraining opportunities to younger workers. Nonetheless the pressure to work remains, because pensions in the UK have not kept pace with inflation and modest spending on social security has lowered the social status of older people.

In a further extension of the debate, Walker (2005) highlights the qualitative aspects of social care, both in care homes and community settings, which tend to reinforce dependency and encourage passivity regardless of health. What all this amounts to is the social construction of dependency in old age, the result of social and economic policy operating in tandem. We now need to look at how the construction of dependency in old age became a central plank of UK community care policy.

\section{The social construction of UK community care policy}

The health and social welfare of older people has traditionally been dominated by notions of care, containment and cost, rather than prevention and healthy ageing, a legacy of $19^{\text {th }}$ century social policy (Payne, 1995; Grell, Cunningham and Jütte, 2017). Social inequalities in health have not reduced over the past 40 years and mortality and morbidity rates across Europe still reveal a strong social class gradient (Bakker and Mackenbach,
2003). In the UK by the late 1980 s, following publication of Caring for People (DoH, 1989), the government of Margaret Thatcher used demographic trends and cost projections to argue that they were sitting on a "resources time bomb". Community care was proposed as the most cost-effective way forward. In adult services this meant developing a mixed economy of provision, involving the fragmentation of state services, centralised control and increased marketization with an enhanced role for the private and voluntary or 'third sector'. According to many influential writers this policy package would inevitably lead to the residualisation of public services (Means, Richards and Smith, 2008; Walker, 2005; Payne, 1995).

The basic problem with the UK community care reforms was that they were implemented on a rather thin evidence base and followed a long tradition of unsuccessful policy masked by political rhetoric. For many, Community Care policy had inherent limitations arising from a significant shortfall in relation to both 'Community' and 'Care'. The 'community ideal' is informed by two opposing traditions. The first, a more conservative belief in community as mutual aid and voluntarism that promotes individual responsibility. The second, the more radical belief that community can foster social integration and become the site for collective responses to adversity and oppression. It was the first tradition that informed policy in the UK.

Unsurprisingly, the community care reforms contained a fundamental contra- 
diction between developing more responsive and empowering services, offering service users greater choice, and achieving better value for money through greater use of the market to contain costs (Thompson and Thompson, 2005; Wistow, 1995). Many older people, as a recent Swedish study concluded, found their role as consumers in the new care market confusing and problematic (Vamstad, 2016). This mirrors the experience of older people in the UK (Glendinning, 2009).

As the mixed economy of care unfolded, the mismatch between policy rhetoric and practice realities soon began to emerge: community services became market rather than needs led; cost containment was accorded a higher priority than user empowerment; institutional styles of care and control lived on often in various disguises, medical professionals retained their dominant role in multi-disciplinary teams despite criticism and talk of a "Berlin wall" between health and social services (Glasby, 2003). We must now look at the tension between health and social care in more detail.

\section{The shifting boundary between Health and Social Care}

At the time when the UK community care reforms were being formulated health care policy was undergoing a significant change in emphasis towards a more cost effective, curative and market orientated service. During this period Wistow (1995) argued that the driving force within Britain's National Health Service (NHS) was the introduction of an efficiency index which measured responsiveness to patients need in terms of increased treatment, throughput and waiting list targets. The community care reforms by contrast were founded, at least in theory, on 'holistic assessments of need, individual care packages and the empowerment of service users to make informed choices' (Wistow, 1995, p. 234).

The community care reforms were implemented at a time when hospital provision was changing and, between 1989 and 1994, the number of long stay beds for older people were reduced by $23 \%$ (Wistow, 1995). Recent analysis suggests that this trend has continued and 'despite rising admissions, the number of general long stay and acute beds in NHS hospitals fell from 126,976 in 2006 to 106,374 in 2013' (Smith, et al., 2014, p. 3). Further, if we look at hospital admissions by age group we find that there was a ' $25 \%$ increase in admissions of older people aged $65-84$, and a dramatic $43 \%$ increase in those aged 85 and over' (Smith et al., 2014, p. 4). This understandably created tensions between health and social care at a time of restricted budgets and led to new problems, including so called "bed-blocking" and the premature discharge of older people (Ford and Stepney, 2003). We will return to this again later.

The general picture which emerges from the research literature is that, despite these problems, progress has been made towards integrating health and social care and developing better collaboration between staff. The most noticeable progress has been in developing creative packages 
of care for older people requiring intensive community support. However, there is evidence of increasing pressure on resources, tighter eligibility criteria, more charging and some 'rationing', especially for those with lower care needs (Mortimer and Green, 2015). Reports from older people and their carers suggest that while some aspects of their care have been positive they have yet to experience significant improvements and that empowerment still remains largely rhetoric rather than reality (Themessel-Huber, Hubbard and Munro, 2007; Walker, 2005).

The fundamental problem undermining better collaboration between health and social care is that while the case for integration was accepted, it was undermined by severe budgetary restraint. Without the necessary resources public services struggled to cope with demographic change and growing demand, while ageist discrimination and exclusion continued in what was called an "age of advanced marginality" (Wacquant, 2007). These problems were Europe wide, so we must situate UK social policy within a wider European context, and examine competing models of social welfare in Europe.

\section{Four European Social Models}

"The challenge is to conceive and implement social reform aimed at greater economic flexibility and better social protection" (André Sapir, 2013, p. 5)

If older people face a number of common problems, such as ageism, dependency, exclusion and restricted access and quality of care, then the response from European governments has been marked by considerable diversity (Sapir, 2013). These differences are historic and can be traced back to different systems of social protection. The seminal work of Esping-Andersen (1990) has been extremely influential in identifying three welfare state typologies, which can be analysed in terms of commodification and stratification - the extent to which state welfare offers protection against the commodifying effects of the market and reduces class-based outcomes.

The three original typologies have established the framework for much subsequent comparative social policy research. First, there are the liberal welfare regimes, characterized by the UK and US that have very modest levels of welfare benefits (pensions, disability, sickness benefits), but more extensive "safety nets" through means tested social security and targeted support for the working poor. Second, are the corporatist welfare states epitomized by Germany, which have more generous social insurance benefits, financed by contributions from earnings. The disadvantage is that these perpetuate income inequalities, favouring men over women, and penalizes those outside the labour market. Third, are the social democratic welfare states of the Nordic countries that have extensive welfare services financed by high levels of taxation and social insurance contributions. In Sweden and Finland, the welfare state is viewed as contributing to social solidarity, such that 
Figure 2: Four European Social Models

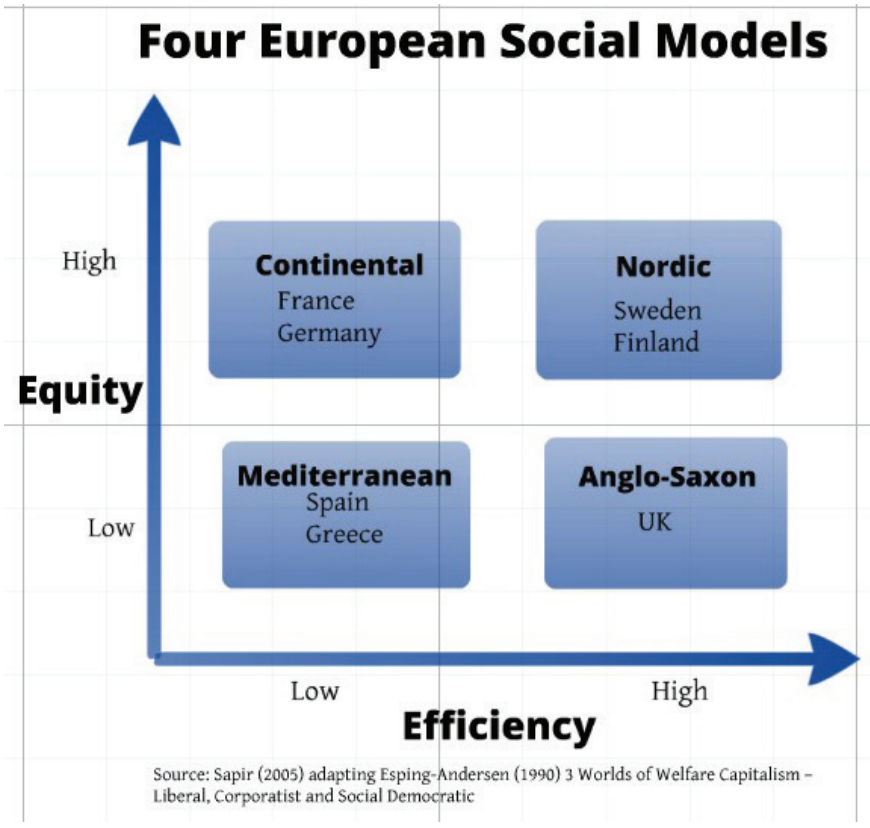

Source: Stepney, 2018

redistribution and universalism receive widespread public support.

The three typologies have been reformulated by Sapir (2013) to include a fourth model based upon the Mediterranean countries (see Figure 2), comparing welfare states on the basis of equity and efficiency.

The four regimes have responded rather differently to the crisis in LTC and challenge of offering older people more choice and support, and constraining welfare costs through adherence to the diktat of the global market.

The liberal Anglo-Saxon model in the UK has championed social deregulation, marketization and privatization. This has widened inequalities between affluent older people and those pensioners dependent on state benefits, with many now at risk of poverty. There has been a growth in low-status service work in the new social care market, employing mainly women and new migrants.

In the continental welfare states like Germany, unemployment has remained quite high, but tackling social exclusion rather than poverty remains a priority. Social care services are mostly in the "third sector," but do not employ large numbers. According to Sapir (2013) although the continental model is equitable, reform is still required to improve efficiency and tackle inequalities.

In the Nordic countries the "Nordic Model of Welfare', despite some retrenchment, retains a strong commitment to equality and social solidarity (Kananen, 
2014). The Nordic countries have the highest rates of social redistribution and lowest poverty levels in Europe (Sapir, 2013). Older people typically live in service flats with flexible support and do not expect to be cared for by their children. Nonetheless, public welfare is expensive due to an extensive bureaucracy, staffed largely by women, and this segmentation of female employment is acknowledged as a problem.

In the Mediterranean countries employment protection and support for older people are priorities. The family plays an active role in welfare for older people who need care (Hantrais, 2004) putting pressure on women to provide informal care. The Mediterranean model typically has low redistribution rates and high numbers of older people at risk of poverty. This means it is seen as the least equitable and efficient of the four models and in need of reform (Sapir, 2013).

The following brief practice vignette illustrates the issues facing older people needing care and how location in Europe influences the outcome.

\section{Practice Vignette}

Agneta is a frail older woman who is waiting to be discharged from the city hospital after recovering from pneumonia. An assessment of her health and care needs has revealed that she has angina and is on the borderline of remaining independent/ requiring residential care. She has one daughter who lives in a nearby town who works full time. While Agneta is mobile and wishes to maintain her independence in her small flat, she is willing to consider the various options.

Based upon the different types of care for older persons that might typically be available in different European localities, we examine the various LTC options for Agneta. Acknowledging that there are many country wide and regional variations, such that caution is advised in discussing options and making recommendations. The question to be asked is - which European social model provides the most helpful policy framework for delivering effective LTC for vulnerable citizens like Agneta?

If Agneta was subject to either the Anglo-Saxon or Continental models she would be offered a package of care to support her at home, the main difference being that in the UK this would likely be from a private provider while in Germany it would be from a 'third sector' agency. Privatisation and marketization of care is developing in Germany, but at a slower rate than the UK. In both countries the care would be monitored and reviewed for effectiveness. At review in the UK a decision would be made about LTC (residential or home care) based upon a risk assessment, cost and Agneta's wishes but with downward pressure to select the cheapest option. In Germany there would be more choice, but that relates to Agneta's social insurance status and health. Agneta's daughter would be consulted especially if she contributed informal care.

In the Mediterranean model typical of Southern Europe Agneta would be more 
dependent upon informal care as both home care and residential care are undeveloped by comparison with the Nordic countries and continental Europe. The number of LTC beds has begun to increase in recent years as more women, who do most of the caring, have entered the labour market (Spasova et al., 2018) and expenditure on social care as a percentage of GDP is now increasing (EU Commission, 2018). Hence, Agneta's daughter and perhaps other carers would have a major say in any decision about LTC. Home care support is desirable but may be difficult to access due to an excess of demand over supply, whereas residential care would be seen as an outcome of last resort.

In the Nordic countries home care is extremely well developed, well-regulated and supported by state agencies. Pensions are also the highest in Europe so Agneta will have options to buy in additional support if needed. Health care is also closely integrated with social care so Agneta should receive high quality monitoring of her heart condition and integrated social support. There has been some retrenchment of public services in recent years alongside limited marketisation (Antonnen and Häikiö, 2011), nonetheless high quality LTC is the norm. It is likely that Agneta lives in a service flat which is linked to a network of integrated services. This means that if her level of dependency increases over time, she will be able to access additional services and support. There would be no expectation in the Nordic model that her daughter would offer informal care.
After our examination of different European social models, which highlighted the advantages of the Nordic approach for delivering effective LTC to frail older citizens like Agneta, we return now to the situation in the UK. Here three trends stand out: the reduction in hospital beds, the growing emphasis on risk and difficulties with working at the shifting boundary between health and social care. Responses to these trends have increasingly began to shape professional social work agendas.

\section{The reshaping of social work practice}

Given the inbuilt tensions within UK community care policy, prevention was seen as a laudable service objective but one that only happened on a good day, something to be done tomorrow rather than today (Stepney, 2014). Unsurprisingly, the focus on social inclusion and well-being, that featured in 'policy mission statements' and acknowledged as important, quickly became subordinate to market consumerism and the drive to increase efficiency and contain costs (Thompson and Thompson, 2005). Similar trends have subsequently emerged, albeit on a smaller scale, in the Nordic welfare states of Finland and Sweden (Antonnen and Häikiö, 2011; Vamstad, 2016).

One overarching narrative that increasingly dominates professional concerns and priorities, in both mainstream services as well as voluntary or 'third sector' agencies, concerns the concept of risk. Discourses of risk now permeate 
assessment processes and have superimposed themselves on traditional concerns about care and support (Stepney, 2018). In the UK assessing, monitoring and managing risk has become a core task, especially in statutory social services - a trend reinforced by legislation and policy directives. While this emphasis is understandable it contradicts the original vision of community care as an empowering service promoting independence and choice. Recent reforms to UK social care have been introduced, based upon policies of personalisation, self-directed support and individual financial budgets (Lymbery, 2012). However, this is a consumerist approach which does not readily connect with the everyday experience of vulnerable older people, who increasingly live in the shadow of the market and would be better served by more emphasis on prevention, empowerment and rights (Stepney, 2014).

Practitioners are increasingly trying to develop more holistic and integrated approaches to client need that recognize the disabling impact of ageism, dependency and social disadvantage. Consequently, accompanying the growing emphasis on risk in mainstream services is a focus on empowerment which reflects the growing interest in the mental well-being of older people, including spirituality - 'how each of us seeks meaning, purpose and direction in our lives' (Thompson, 2019, p. 37). Well-being is a holistic umbrella term concerned with the quality of modern life and the need to search for greater happiness, contentment and meaning, to counteract problems of disconnection, exclusion and loneliness in old age (Thompson, 2019).

The promotion of well-being, has become one of the primary aims of modernized social services, and by introducing a term of common purpose has created conditions for new partnerships between health, social care and voluntary or 'third sector' agencies. The search for new partnerships, especially between health and social services, highlight the need for enhanced collaboration between staff on the front line.

\section{Collaborative working}

Collaborative working is an approach informed by a cluster of concepts, such as, 'inter-professional', 'cooperation', 'team working', and 'partnership', which all tend to be used in somewhat different ways depending on the organisational and professional context (Leathard, 2011; Stepney, 2018). At its simplest collaboration infers that staff from different professional and academic backgrounds form a working relationship or partnership for the purpose of delivering enhanced services. However, as a recent study in thirteen European countries found, the exact nature of the partnership is likely to be contested, whilst fully integrated, person centred, 'joined-up' provision has so far proved elusive (Stoop et al., 2020).

At the heart of the debate about collaboration is a certain sense of professional ambivalence. On the one hand a great deal has always been claimed for collaborative working, in both the policy 
and professional literature. On the other hand there are countless examples of problems and tensions arising whenever these ideas are put into practice (Kharicha et al., 2004). According to many writers, (see for example Payne, 1995; Lymbery, 1998; Leathard, 2011; Stepney, 2014) collaborative working has considerable potential for making a positive difference and improving services for older people, nonetheless it continues to be fraught with difficulties.

Although the merits of collaborative working have rarely been disputed, its application in social work has largely been in the high risk settings of child protection and mental health rather than in services for older people. This is a great pity as collaborative work has the potential for developing strategies of preventive that could enable older people to live independently and safely for longer in the community. In the context of the present Covid-19 crisis the need for collaboration could not be higher - a view consistent with the recent statement by Hans Kluge of the World Health Organisation (WHO) "Supporting and protecting older people living alone in the community is everyone's business," (Kluge, 2020). The need for collaboration was again stressed in the WHO August 2020 edition of European Public Health (EPH) news (Leyland and Kluge, 2020). This is something that emerges in the three contemporary issues of concern that we will now examine.

\section{Three contemporary issues of concern}

\section{(I) Hospital discharge of older people}

When I first conducted research on this issue, I discovered that while the problem of "delayed discharge" or so called "bed blocking" certainly existed, a potentially more serious problem was quite common and likely to be overlooked. I refer here to the problem of premature discharge (Ford and Stepney, 2003). The research literature then as now tends to highlight the first problem (Glasby, 2003; Challis, et al., 2013), due to delays in setting up home care, finding a suitable care home or funding disputes, but under-reports the problem of older people sometimes being rushed out of hospital prematurely to free up an acute or long stay bed. Further, my research findings published in the European Journal of Social Work have rarely been cited. Hence, the problem of premature discharge of older people remains largely unacknowledged.

The current Covid-19 crisis has brought the problem to the surface again, in particular, the untimely transfer of older people from hospital to care homes without being tested for the virus. The resulting high number of deaths is seen as a policy failure, not confined to the UK. The problem of excess deaths in care homes has emerged in other European countries, particularly Spain and Belgium despite testing for the corona virus being more extensive, and to a less extent in Sweden and France. Sweden was an outlier 
compared to other European countries in rejecting a lockdown policy but was still unable to prevent excess deaths in care homes (Figure 3).

The number of residents dying in UK care homes, as a percentage of all care home residents, was approximately double that of France and Sweden, and 13 times higher than in Germany. This meant that around 3,500 older people died in care homes in Germany compared with 16,000 in the UK, despite Germany having a far
At one time every major hospital had a social work team on site, who took responsibility for discharge planning. Today that is no longer the case and discharge arrangements have been streamlined and undertaken by different nursing and administrative staff, sometimes in a hurry. A common set of EU standards and indicators to ensure quality is needed to ensure older people receive the help and support they need when they leave hospital.

Figure 3: Deaths attributed to Covid-19, expressed as a percentage of all care home residents, in selected European countries

\begin{tabular}{|l|l|l|l|l|l|l|}
\hline & $1.00 \%$ & $2.00 \%$ & $3.00 \%$ & $4.00 \%$ & $5.00 \%$ & $6.00 \%$ \\
\hline Spain 6.1 & & & & & & \\
\hline UK 5.3 & & & & & & \\
\hline Belgium 4.9 & & & & & & \\
\hline Ireland 3.2 & & & & & & \\
\hline Italy 3.1 & & & & & & \\
\hline Sweden 2.8 & & & & & & \\
\hline France 2.4 & & & & & & \\
\hline Denmark 0.5 & & & & & & \\
\hline Slovenia 0.5 & & & & & & \\
\hline Germany 0.4 & & & & & & \\
\hline Norway 0.4 & & & & & & \\
\hline
\end{tabular}

Source: Booth, 2020, Guardian graphic, 29 June 2020, London School of Economics

larger care home population. The reason can be attributed to Germany's extensive test-and-trace system and 14-day quarantine for anyone leaving hospital.

Once the corona pandemic subsides the time has come for a re-appraisal of hospital discharge protocols everywhere, particularly for frail older people like Agneta at the home/residential care boundary. (ii) Risk management dilemmas in practice

As the concept of risk has come to permeate health and social care policy and practice agendas, the problem of devising effective risk management systems and procedures requires urgent attention. Older people are often at the sharp end of 
decisions made about their LTC following a risk assessment. Recent research (Taylor, 2005) has uncovered a fundamental problem, in that agency risk management procedures do not always match the conceptual framework of the professionals involved. Further, the paradigms of risk used by professionals in care management manuals contain in built contradictions and tensions. Taylor (2005) found that the paradigm of resources control and efficiency or throughput priorities conflicted with meeting needs and addressing protection measures. This made the professional task of assessing risk more problematic.

Another related issue is that while the requirement to minimise hazards is clearly a worthwhile aim, the question of what constitutes an allowable hazard remains unresolved and is a matter of professional judgement. When an older person is assessed for home care various hazards may be identified - for example, correct medication to be taken, traffic outside her flat if she goes out, the gas fire in her lounge, sharp utensils in the kitchen, the step into the bath or shower and so on. All these low level hazards present a risk which must be recognised if the older person is to live independently at home. The professional could of course help to minimise them by adopting a person-centred approach (Stoop et al., 2020) and discuss risks with the older person and perhaps suggest that they wear a safety alarm. The visits from home care staff can help by monitoring and supporting where required to ensure that risk is managed in an integrated and person-centred way.
Thus risk management dilemmas can be contained by adopting an integrated person-centred approach (Stoop et al., 2020).

\section{(iii) The escalating cost of LTC}

One of the most serious problems identified by research and indeed often the older person themselves concerns the affordability and cost of LTC. This was seen as an important issue back in the 1980 s at the outset of community care when de-institutionalisation was gathering momentum (Payne, 1995; Wistow, 1995). It now features strongly in recent EU publications which address the financial sustainability of LTC (Spasova, et al., 2018; European Commission, 2018). The problem is that, given demographic trends and projected costs, no viable and politically acceptable solution has hitherto been found. It is the classic policy problem replete with numerous political banana skins that have persuaded politicians to kick the issue into the long grass and leave it for the next government to solve. Plus ça change, plus c'est la même chose.

Adequate and sustainable funding of LTC is seen perhaps as one of the greatest challenges facing every European government today. The challenge is to meet future demand, given that research suggests that demand has begun to accelerate and will probably reach a peak around 2040 (Karlsson et al., 2006). It is likely that the most significant demand will be for home care supplemented with informal care and supported by low level services. Demand for home care is projected to rise from 
2.2 million places in 2006 to 3 million by 2050 . This means that expenditure on home care will rise accordingly from $£ 11$ billion in 2006 to an estimated $£ 15$ billion in 2040 (at 2001 prices) (Karlsson et al., 2006). These figures do not include projected costs of residential care and take into account regional variations. Consequently, EU wide solutions must be found to the escalating cost challenge and for policy makers to adopt the recommendations in influential EU reports that call for "more effective and cost-efficient measures...a stronger emphasis on rehabilitation and social investments including prevention strategies' (Spasova et al., 2018, p 4).

\section{Conclusions}

We have covered a lot of ground in this article examining the ongoing crisis in the LTC of older people with critical scrutiny of the UK's market led approach alongside reference to the situation in other European countries. The policy debate was informed by reference to different European social models, highlighting the strength of the Nordic model, and the EU report on LTC (Spasova, et al., 2018). The policy on LTC for older people was linked to the reshaping of professional practice, the need for collaboration between health and social care, and illustrated with reference to a number of contemporary issues - including hospital discharge, managing risk and issues of affordability, sustainability and cost. The problem of cost being the one that EU leaders find the most pressing but intractable.

At present expenditure within the EU on long term home care is highest in the Nordic countries and the Netherlands (European Commission, 2018). However, it should be remembered that only a relatively small part of health spending is devoted to LTC, the largest part is of course on acute in-patient care. If community care is going to meet the needs of Europe's ageing population, then spending needs to be re-balanced from acute care to LTC, especially home care. The cost, affordability and quality of LTC remain important issues and while policy recognises the importance of informal care, and to an extent over relies on women's domestic labour, much more needs to be done to support carers. Supporting carers supports the older person as well (Van Eenoo, et al., 2016) and this is but one of many issues requiring Europe wide action.

There are a number of positive steps that could now be taken to counteract policy inertia, improve existing care for older people and make the future of LTC more sustainable. The key may well be in the dual concepts of prevention and rehabilitation (Stepney, 2014). The high value of low-level support has traditionally been under-estimated. However, research suggests that older people themselves place a high value on services that meet their so called 'low-level' needs (Clark, Dyer and Horwood, 1998). This informs the following recommendation for practice. 


\section{Recommendation for practice}

There is a strong case for developing more extensive community based preventative services and investing in rehabilitation, integrated provision and person-centred home care, especially for older people leaving hospital. There is importantly good research evidence to support this (Stepney, 2014; Van Eenoo, et al., 2016; Spasova et al., 2018). It will certainly have a short-term cost, but could prove a wise investment that will enhance sustainability, promote integration of services and bring many long-term benefits.

\section{References}

Antczak, R. and Zaidi, A. (2016). Risk of Poverty among Older People in EU Countries. CESifo DICE Report, ISSN 1613-6373, ifo Institut - Leibniz-Institut für Wirtschaftsforschung an der Universität München, München, 14 (1), pp. 37-46.

Anttonen, A., J Baldock, J. and Sipilä, J. (Eds) (2003). The Young, the Old, and the State: Social care systems in five industrial nations. Cheltenham, UK: Edward Elgar.

Antonnen, A. and Häikiö, L. (2011). Care 'going market': Finnish elderly-care policies in transition, Nordic Journal of Social Research, Special Issue 2, pp. 70-90.

Aquino, J., Russell, D., Cutrona, C. and Altmaier, E. (1996). Employment status, social support and life satisfaction among the elderly. Journal of Counselling Psychology, 43(4), pp. 480-489.

Bakker, M. and Mackenbach, J. (Eds) (2003). Reducing Inequalities in Health: A European Perspective. London: Routledge.

Barnett, K., Mercer, SW., Norbury, M., Watt, G., Wyke, S. and Guthrie, B. (2012). Research paper. "Epidemiology of multimorbidity and implications for health care, research, and medical education: a cross-sectional study." The Lancet online. https://oi.org/10.1016/ S0140-6736(12)60240-2

Booth, R. and Duncan, P. (2020). More than 16,000 people in UK care homes have died from coronavirus. The Guardian, 16 June 2020.

Booth, R. (2020). Covid-19: risk of death in UK care homes 13 times higher than in Germany. Source : London School of Economics, The Guardian, 28 June 2020.

Centre for Policy on Ageing (1990). Community Life: A Code of Practice for Community Care. London: Centre for Policy on Ageing.

Challis, D., Hughes, J., Xie, C. and Jolley, D. (2013). An examination of factors influencing delayed discharge of older people from hospital, International Journal of Geriatric Psychiatry, 29 (2), pp. 160-168.

Clark, H., Dyer, S. and Horwood, J. (1998). That bit of help: The high value of low level preventative services for older people, Bristol, UK: Policy Press.

Department of Health (DoH). (1989). Caring for People: Community Care in the next decade and beyond. $\mathrm{Cm} \mathrm{849,} \mathrm{London:} \mathrm{HMSO.}$

Eenoo, L V., Declercq, A., Onder, G., Finne-Soveri, H., Garms-Homolová, V., Jónsson, P., Dix, O., Smit, J., van Hout, H. and van der Roest, H. (2016). European Journal of Public Health, 26(2) April 2016, pp. 213-219. 
Esping-Andersen, G. (1990). The Three Worlds of Welfare Capitalism. Cambridge: Polity Press. European Commission (2018). 2018 Ageing Report: Policy challenges for ageing societies. 25 May 2018, EU Commission, Brussels.

Eurostat (2018). Eurostat Regional Yearbook 2018, Luxembourg: European Commission. (www.europa.eu.int/comm/eurostat) Available from: https://ec.europa.eu/eurostat/web/ products-statistical-books/-/KS-HA-18-001 [accessed 06.10.2020].

Ford, D. and Stepney, P. (2003). Hospital discharge and the citizenship rights of older people: will the UK become a test-bed for Eastern Europe? European Journal of Social Work, 6(3), pp. 257-273.

Glasby, J. (2003). Bringing down the 'Berlin Wall': the Health and Social Care Divide, British Journal of Social Work, 33 (7), pp. 969-975.

Glasby, J. (2003). Hospital Discharge: Integrating Health and Social Care, Abingdon, UK: Radcliffe Medical Press.

Glendinning, C., (2009). The Consumer in Social Care. In R. Simmons, M. Powell and I. Greener (Eds) The Consumer in Public Services: Choice, values and difference. Bristol: Policy Press.

Grell, O.P., Cunningham, A. and Jütte, R. (2017). Health Care and Poor Relief in 18th and 19th Century Northern Europe. New York: Routledge.

Hantrais, L. (2004). Family Policy Matters: Responding to Family Change in Europe, Bristol, UK: Policy Press.

Holloway, M. and Moss, B. (2010). Spirituality and social work. Basingstoke, UK: Palgrave Macmillan.

Kananen, J. (2014). The Nordic Welfare State in Three Eras: From Emancipation to Discipline, Farnham, UK: Ashgate.

Karlsson, M., Mayhew, L., Plumb, R. and Rickayzen, B. (2006). Future Costs for Longterm Care: Cost projections for LTC for older people in the UK. Health Policy, 75 (2), pp. 187- 213.

Kharicha, K., Levin, E., Iliffe, S. and Davey, B. (2004). Social work, general practice and evidence-based policy in the collaborative care of older people: current problems and future possibilities, Health and Social Care in the Community, 12 (2), pp. 134-141.

Kluge, HHP (2020). Supporting older people during the COVID-19 pandemic is everyone's business. World Health Organisation Statement, 2 April 2020, Copenhagen, Denmark: Dr Hans Henri P. Kluge, WHO Regional Director for Europe.

Leathard, A. (ed) (2011). Inter-professional Collaboration: From Policy to practice in health and social care. New York: Routledge.

Leyland, A. and Kluge, HHP. (2020). European Public Health News. European Journal of Public Health, 30 (4) August 2020, pp. 842-844. Available from: https://doi.org/10.1093/ eurpub/ckaa151 [Accessed 07.10.2020].

Lymbery, M. (1998). Social Work in General Practice: dilemmas and solutions, Journal of Inter-professional Care, 12 (2), pp. 199-208.

Lymbery, M. (2012). "Social Work and Personalisation." British Journal of Social Work 42(4) pp. 783-792.

Means, R, Richards, S. and Smith, R. (2008). Community Care: Policy and Practice, $4^{\text {th }} \mathrm{ed}$, Basingstoke, UK: Palgrave Macmillan. 
Mortimer, J. and Green, M. (2015). Briefing: The Health and Social Care of Older People in England, London: Age UK.

Payne, M. (1995). Social Work and Community Care. Basingstoke, UK: Macmillan.

Sapir, A. (2013). Globalisation and the Reform of European Social Models, Breugel Policy Brief, Brussels Available from: (www.slideshare.net/bluelucy/globalisation-and-the-reform-of-european-social-models) [accessed 01.10.2020].

Smith, P., McKeon, A., Blunt, I. and Edwards, N. (2014). NHS hospitals under pressure: trends in acute activity up to 2022. London: Nuffield Trust.

Spasova, S., Baeten, R., Coster, S., Ghailani, D., Peña-Casas, R. and Vanhercke, B. (2018). Challenges in long-term care in Europe. A study of national policies, European Social Policy Network (ESPN), Brussels: European Commission.

Stepney, P. (2014). "Prevention in Social Work: The final frontier?" Critical and Radical Social Work 2(3): 305-320.

Stepney, P. (2018). Theory and Methods in a Policy and Organisational Context: International Perspectives. In N. Thompson and P. Stepney (eds) Social Work Theory and Methods: The Essentials.pp. 44-62, New York: Routledge.

Stoop, A., Lette, M., Ambugo, E., Wirmann Gadsby, E., Goodwin, N., Macinnes, J., Minkman, M., Wistow, G., Zonneveld, N., Niipels, G., Baan, C. and de Bruin, S. (2020). Improving Person-Centredness in Integrated Care for Older People: Experiences from Thirteen Integrated Care Sites in Europe. International Journal of Integrated Care. Apr-Jun; 20(2): p. 16. Available from; doi: 10.5334/ijic.5427 [accessed 07.10.2020].

Taylor, B. (2005). Risk Management Paradigms in Health and Social Services for Professional Decision Making on the Long Term Care of Older People, British Journal of Social Work, 36 (8), pp. 1411-1429.

Themessel-Huber, M., Hubbard, G. Munro, P. (2007). Frail older people's experiences and use of health and social care services, Journal of Nursing Management, 15 (2): pp. 222-229.

Thompson, N. and Thompson, S. (2005). Community Care. Lyme Regis, UK: Russell House. Thompson, N. (2019). Mental Health and Well-Being: Alternatives to the Medical Model: New York: Routledge.

Vamstad, J. (2016). Exit, voice and indifference - older people as consumers of Swedish home care services. Ageing \& Society, 36 (10), pp. 2163-2181.

Walker, A. (ed) (2005). Understanding quality of life in old age. Maidenhead, UK: Open University Press.

Wacquant, L. (2007). Territorial stigmatisation in an age of advanced marginality. Sage Publications and Thesis Eleven, 91, pp. 66-77.

Wistow, G. (1995). "Aspirations and Realities: community care at the crossroads." Health and Social Care in the Community 3(4), pp. 227-240. 